\title{
Status of southern right whales (Eubalaena australis) off Australia
}

\author{
JOHN BANNISTER \\ The Western Australian Museum, Francis Street, Perth, Western Australia, 6000 \\ Contact e-mail: 106174.3301@compuserve.com
}

\begin{abstract}
The history of Australian right whaling is briefly reviewed. Most catching took place in the first half of the 19th century, with a peak in the 1830 s, involving bay whaling by locals and visiting whaleships in winter and whaling offshore in the summer. In the early 20 th century, right whales were regarded as at least very rare, if not extinct. The first published scientific record for Australian waters in the 20th century was a sighting near Albany, Western Australia, in 1955. Increasing sightings close to the coast in winter and spring led to annual aerial surveys off southern Western Australia from 1976. To allow for possible effects of coastwise movements, coverage was extended into South Australian waters from 1993. Evidence from 19th century pelagic catch locations, recent sightings surveys, 1960s Soviet catch data and photographically-identified individuals is beginning to confirm earlier views about likely seasonal movements to and from warm water coastal breeding grounds and colder water feeding grounds. Increase rates of $c a 7-13 \%$ have been observed since 1983 . Some effects of different breeding female cohort strength are now beginning to appear. A minimum population size of $c a 700$ for the period $1995-97$ is suggested for the bulk of the 'Australian' population, i.e. animals approaching the $\mathrm{ca} 2,000 \mathrm{~km}$ of coast between Cape Leeuwin, Western Australia and Ceduna, South Australia.
\end{abstract}

KEYWORDS: SOUTHERN RIGHT WHALE; AUSTRALASIA; SURVEY-AERIAL; DISTRIBUTION; TRENDS; ABUNDANCE ESTIMATE

\section{INTRODUCTION}

As elsewhere in the Southern Hemisphere, right whales were considered very rare, if not virtually extinct, in Australian waters for at least the first half of the $20^{\text {th }}$ century. More than 100 years earlier, people had been aware of their presence in some numbers in suitable coastal areas in winter: in 1804 they were regarded as such a danger to navigation in the Derwent River, Tasmania, that small boats had to keep close to the shore. Up to 50 or 60 animals could apparently be seen there in the shallows between May and November; in Hobart $\left(42^{\circ} 55^{\prime} \mathrm{S}, 147^{\circ} 20^{\prime} \mathrm{E}\right)$ the Lieutenant-Governor is said to have been kept awake by their 'snorting' at night (Dakin, 1934).

The development of Australian shore-based whaling from 1805, particularly along the southeast coast of Tasmania, off western Victoria, South Australia and southern Western Australia, was accompanied by the operations of Tasmanian registered sailing vessels in bays as far afield as New South Wales and even New Zealand. In addition, the pelagic vessels from the USA, Britain and France that operated in the high seas in the summer were attracted to coastal areas in winter. By the late 1830 s, as many as 50 shore stations were recorded from southeast Australia, although some may have been temporary sites used only for one season. Dawbin's (1986) estimate of the scale of killing from these combined sources - a minimum of 26,000 animals off New Zealand and southeast Australia between 1827 and 1899, with 75\% taken in the ten years 1835-44 - is telling enough. It is even more so if, as Dawbin acknowledges, account is taken of losses of possibly up to $20 \%$ after harpooning and the lack of information on at least the British element of the fishery.

Clearly the stocks could not withstand such pressure. Off Western Australia, where right whaling began rather later than off southeast Australia, there were reports such as 'foreigners .... infest our bays from the beginning of May to the end of October [1839]', and 'every year now [1840] at the end of December, during January, February and March the [American] fleet could be expected' (Heppingstone, 1969, cited in Bannister, 1986). The scale of the pelagic operations can be gauged from the combined catch of 57 right whales by three American vessels in the summer of 1840-41. In coastal waters, at Fowlers Bay, South Australia, one vessel alone, the Amazon, took 33 right whales in a little under three months from June-August 1840 (Bannister, 1986). No wonder that in late 1849, Nelson Cole Haley on the Charles W Morgan at Two Peoples Bay (3457'S, $\left.118^{\circ} 12^{\prime} \mathrm{E}\right)$ on the Western Australian south coast recorded: 'Some years ago whale ships came here in certain seasons to catch right whales, but it has been abandoned now for that purpose' (Haley, 1950).

The pelagic right whale fishery off Western Australia peaked in the late 1830 s and rapidly declined. By about 1850, the offshore 'Coast of New Holland Ground' had ceased to be attractive to foreign right whaling vessels. The last shore-based Western Australian right whale catch was recorded in 1866, when an estimated seven animals were taken (Bannister, 1986). By 1900, interested Australians would have said right whales were virtually extinct, or at least exceedingly rare, anywhere in Australian waters.

When Chittleborough (1956) recorded the sighting of a cow and calf near Albany, WA, in 1955, he was unable to find any published scientific account of an Australian right whale sighting that century. The species' rarity in Australian waters was confirmed by others: Ling and Aitken (1981), commenting on the sighting of a cow and calf off South Australia in 1968, presumed they had been absent from there during the first half of the century. However, an increasing number of sightings off the south coast of Western Australia in the early 1970 s led to annual aerial surveys along that coast from 1976. Other more recent survey work has been undertaken off South Australia and further east (Ling and Needham, 1991; Kemper et al., 1997). Intensive biological studies have been undertaken at the Head of the Bight, South Australia since 1991 (Burnell and Bryden, 1997); since 1995 that work has included animals to the east and southeast, i.e. off Victoria, southern New South Wales and Tasmania (Burnell, 1997). This paper documents some of the main results recently obtained on distribution, numbers and 
increase rates, particularly those derived from the aerial surveys that began off the southern Western Australian coast and were later extended eastwards into South Australia.

\section{DISTRIBUTION}

Late $20^{\text {th }}$ century sightings of Australian right whales have been concentrated in coastal waters of Western and South Australia, and to a lesser extent off Victoria, Tasmania and New South Wales (see Fig. 1). There have been records as far north as Exmouth, WA ( $\left.22^{\circ} 23^{\prime} \mathrm{S}, 114^{\circ} 07^{\prime} \mathrm{E}\right)$, on the north west coast, and north of Sydney (33 $\left.53^{\circ} \mathrm{S}, 151^{\circ} 12^{\prime} \mathrm{E}\right)$ to Cape Byron, NSW (28 $\left.39^{\prime} \mathrm{S}, 153^{\circ} 37^{\prime} \mathrm{E}\right)$, on the east coast, but in general animals are concentrated along the south coast from west of Albany, WA to the Head of the Bight, SA. In some years there have been small concentrations at localities such as Port Lincoln $\left(34^{\circ} 44^{\prime} \mathrm{S}, 1^{\circ} 5^{\circ} 52^{\prime} \mathrm{E}\right)$ and Victor Harbor, SA (35 $34^{\prime}$ S, $\left.138^{\circ} 37^{\prime} \mathrm{E}\right)$ and Warrnambool, VIC $\left(38^{\circ} 23^{\prime} \mathrm{S}, 142^{\circ} 29^{\prime} \mathrm{E}\right)$, while there are fairly regular sightings along the south east coast of Tasmania. The peak of abundance is in August-September, with animals commonly present from late June-early October.

The animals seen most regularly close to the coast are cows accompanied by calves of the year (Bannister, 1990; Burnell and Bryden, 1997). They are only present for long periods in the year of the calf's birth, when they may spend up to three months on the coast before heading south to colder waters, in their summer (presumed feeding) grounds. Other animals are also found close to the coast, relatively frequently but more irregularly, often in sub-adult or adult interactive groups and demonstrating courting and mating behaviour.

Information is now coming to light on the animals' probable summer distribution in colder waters south of the continent. 'Townsend's Charts' for the region ${ }^{1}$ (Townsend, 1935) are consistent with indications from coastal sighting records, 1904-82 (Bannister, 1986), of northwards movement from the south, from Tasmania to Victoria or New South Wales in the early part of the (winter) season and later movement to the south. That was a strongly held view in the $19^{\text {th }}$ century (see Dakin, 1934 and Aitken, 1981, cited in Bannister, 1986; also Dawbin, 1986, in particular citing Cumpston, 1970). An 1842 report (Aitken, 1981) described right whales approaching Tasmania from about the beginning of April, then moving towards western Victoria before continuing westwards to the Great Australian Bight. Additional animals are described as arriving along the whole southern coast direct from the south, then 'at Cape Le[eu]win [south west WA] the great body of whales seems to strike off southward, for in October and November they are again working towards the south east, by keeping two or three hundred miles from land'. Townsend's plots (summarised in Fig. 1) show a well-defined September catching ground close to the south coast of Western Australia, while plots representing October-December catching grounds appear further west and south, and to the

1 Townsend's charts show the positions of American whaling vessels on days when they caught whales (plotted by month).

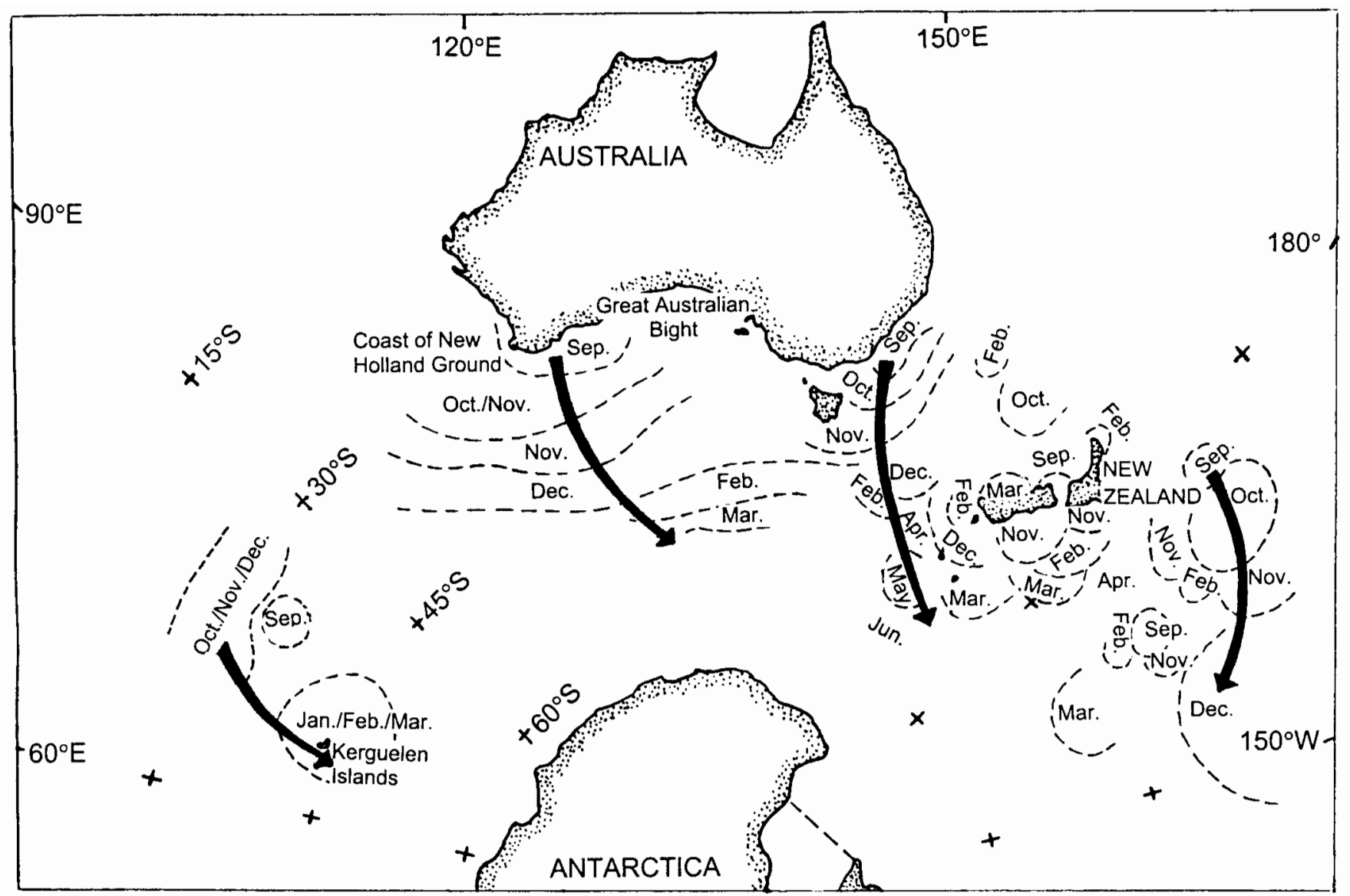

Fig. 1. Monthly positions of southern right whale catches, US $19^{\text {th }}$ century whaling, Australasian region, summarised from Townsend's charts (1935). Inferred seasonal whale movements indicated. 
east towards Tasmania. There are then a few February-March plots approaching Tasmania from the west, south of the Bight.

The expectation that right whales would be found well to the south of Western Australia in early summer is confirmed by Whitecar (1860) on the American whaleship Pacific, in 1856. Leaving Albany, WA, on 5 November, the ship steered south, to $40^{\circ} \mathrm{S}$, '. . . where we expected to see right whales'. They did so, but by that date, the late 1850 s, right whales had become increasingly hard to approach. '. . . [T] he moment the boat was lowered from the ship they absquatulated in as secret and shy a manner as a defaulting bank clerk ... We could do nothing with these shy gentlemen ... . and steered northwest for Cape Le[eu]win ... [for sperm whales]'.

Other well-defined spring-summer changes in catching positions are shown towards the south (Fig. 1). Examples are northeast of New Zealand, and in the southeast Indian Ocean near Kerguelen. There is also a well-marked southward change off southeastern Australia, from New South Wales through the Tasman Sea to the south of New Zealand, and over a wide range of months (September-June). The continuing southward change in early winter is anomalous, but consistent with recent records of winter concentrations at the Auckland Islands, south of New Zealand (Patenaude and Baker, 2001).

While there is no direct evidence that such changes in distribution of catching positions actually reflect whale movements, there are strong implications that they do. However, as usual with such data, they are limited in their coverage by the restrictions of wind, weather and current on sailing ship operations. In the Australasian region, there is no indication on Townsend's charts of right whale catches anywhere south of about $45^{\circ} \mathrm{S}$. That seemed to be borne out by observations of a large concentration, of 75 animals, $41-44^{\circ} \mathrm{S}, 116-124^{\circ} \mathrm{W}$, i.e. south of Cape Leeuwin WA, in December-January 1981-82 (Ohsumi and Kasamatsu, 1986). Nevertheless, a sightings cruise specifically for right whales found none in that area in February-March 1993, while 35 animals were encountered there in December-January 1995-96 (Bannister et al., 1997). Following the lack of success of the 1993 cruise, those involved (including this author) assumed that at that time (February-March, i.e. late summer), right whales must have been further south. Such a possibility had already been demonstrated for right whales off South Africa: using Townsend's data, Best (1970) showed that in the southeast Atlantic and southwest Indian Ocean right whales in late summer can occur at least as far south as $55^{\circ} \mathrm{S}$. The same was hypothesised by Best and Schell (1996) from stable isotope analyses.

The possibility that in late summer right whales in the southeast Indian Ocean may be found even further south, i.e. beyond $60^{\circ} \mathrm{S}$, has been confirmed by sightings of animals at $64^{\circ} \mathrm{S}$ in February 1996 (Bannister et al., 1999), and recent revelations of Soviet catches (of 14 animals) in the same area, i.e. south of $60^{\circ} \mathrm{S}$ between $92-106^{\circ} \mathrm{E}$, in February-March 1963 (Tormosov et al., 1998). The positions of the above sightings and catches are shown in Fig. 2.

Some direct evidence of a link between animals in colder waters in summer and on the Australian coast in winter is now available from photographically-identified individuals (Fig. 2). Two 'matches' have been made between animals identified off either Western Australia or South Australia in winter/spring and in the area at approximately $43^{\circ} \mathrm{S}$ where

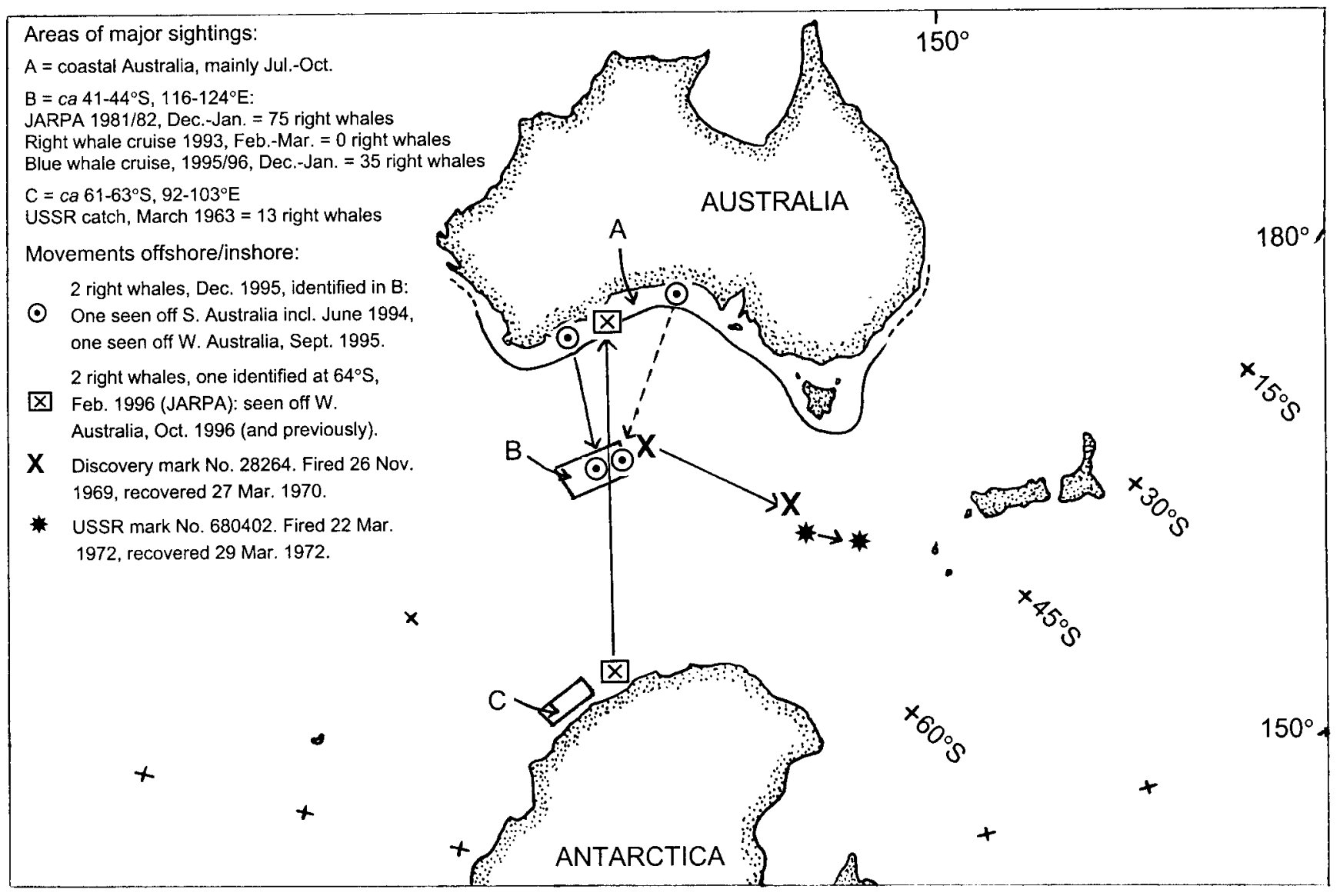

Fig. 2. Southern right whales off Australia: locations of sightings, catches and recorded movements (straight line routes), 1963-96. 
the 35 animals were recorded in December-January 1995-96; the records involve straight line movement of 900 and 1,500 n.miles respectively (Bannister et al., 1997). One animal photographed at $64^{\circ} \mathrm{S}$ in February 1996 had already been identified over a period of some 18 years on the coast of Western Australia, $c a$ 1,700 n.miles due north (Bannister et al., 1999).

Confirmation of likely eastward movement during summer to the south of the continent has come from two Soviet marking returns (Fig. 2), one involving movement of some 900 n.miles from $40^{\circ} 34^{\prime} \mathrm{S}, 124^{\circ} 02^{\prime} \mathrm{E}$ to $47^{\circ} 42^{\prime} \mathrm{S}, 148^{\circ}$ $40^{\prime} \mathrm{E}$ in 122 days ( $\mathrm{ca} 17$ weeks) in late November 1969-March 1970, and another of some 200 n.miles from $47^{\circ} 20^{\prime} \mathrm{S}, 148^{\circ} 40^{\prime} \mathrm{E}$ to $48^{\circ} 00^{\prime} \mathrm{S}, 153^{\circ} 00^{\prime} \mathrm{E}$ over seven days in late March 1972 (Tormosov et al., 1998).

Movements along the southern Australian coast, both within and between years, have been demonstrated by 'matches' of individuals identified in South Australia and Western Australia (Bannister, 1994) and between Tasmania, Victoria, New South Wales, South Australia and Western Australia (Burnell, 1997; 2001). The general coastwise trend seems to be towards the west, in line with earlier expectations; the extent of the reported movements is a strong indication that right whales found along the Australian coastline belong to a single stock.

\section{INCREASE RATES}

The aerial surveys off the south coast of Western Australian had two main aims, to provide: (1) information on relative numbers from year to year, and hence a rate of increase should it be occurring; and (2) a series of photographically identified individuals for information particularly on distribution, movement and other life history parameters. The remainder of this paper is concerned mainly with aim (1).

\section{Survey strategy and area}

The Western Australian aerial surveys have followed the same basic pattern since their inception in 1976. An attempt has been made each year to obtain a maximum count of animals on the coast in a narrow ( $c a 1$ n.mile) band seawards of the beachline. Until 1993, a single engine, high wing monoplane (Cessna 172 or 185), with the same pilot each year, and a single observer/photographer, surveyed the coast along some 600 n.miles $(1,100 \mathrm{~km})$ between Cape Leeuwin in the west and Twilight Cove in the east (Fig. 3). Flight tactics are described in Bannister (1990). Coverage varied over the period. The area was extended to the east from 1983 to accommodate reports of numbers of animals east of Israelite Bay, at the western limit of the Great Australian Bight, and towards Twilight Cove, relatively close to the South Australian border (Fig. 3).

In July-October each year, at least three flights were attempted, to ensure bracketing of the peak period of abundance (mid August - mid September) and provide information on residence times and within-season coastwise movements.

The area surveyed was again extended eastwards in 1993, to include the major calving ground at the Head of the Bight, SA. This followed a review of the programme, given increasing evidence of within- and between-season coastwise movements between South Australia and Western Australia, and to obviate if possible the effect upon the observed increase rate of animals migrating into the 'WA sector' from the east. The survey then covered some 1,100 n.miles $(2,000 \mathrm{~km})$ between Cape Leeuwin, WA, and Ceduna, SA (Fig. 3). Initially the Cessna 185 was used on the extended flight but for fuel economy and safety it was

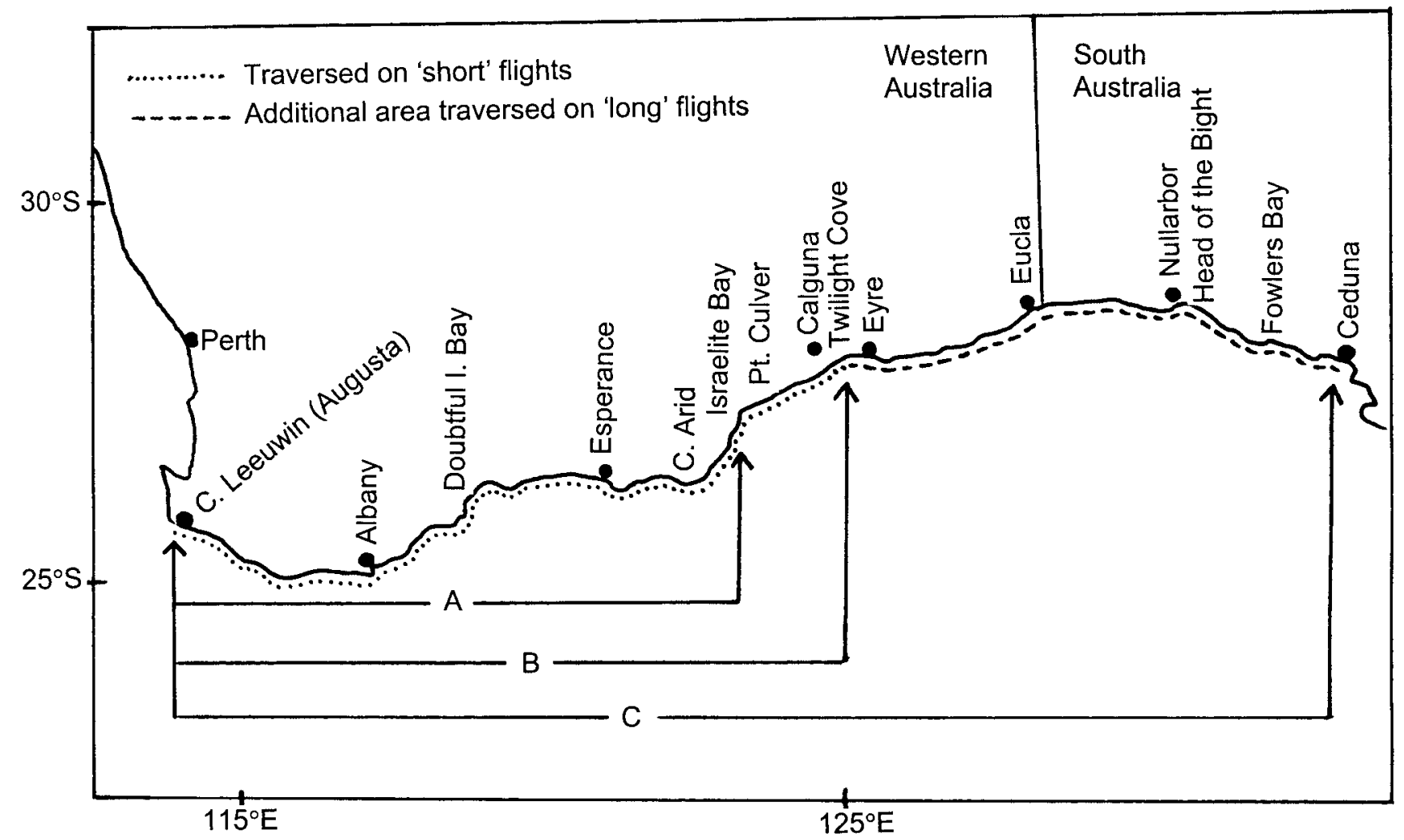

Fig. 3. Southern right whale aerial surveys, southern Australia 1976-97: approximate position of flight paths. A, B, C = limits of flight paths designated as in Tables 1-3 
replaced by a twin-engined Cessna 337 from 1994. Three 'long' flights took place annually at first, but since 1994 they have been replaced by one 'long' flight covering the whole area ('WA-SA sector') at the season peak (mid August-mid September) and two 'short' flights covering the area Cape Leeuwin-Twilight Cove (the 'WA sector') in July/August and September/October.

A power analysis (by P.J. Corkeron, in Bannister, 1993) showed that at least five years' consecutive annual surveys would be required from 1993 to obtain significant evidence of an increase rate. Given the three year calving interval, that was increased to six years to cover two full calving cycles. However, further analysis (Corkeron, in Bannister, 1997) showed that while that might be satisfactory for the population as a whole, including the non-calving element, a much longer period would be necessary to obtain a significant result for calving females (cow-calf pairs). Five cycles would be required, over fifteen years from 1993. While the first six-year cycle would be completed by a survey in 1998, to cover the five calving periods would require a further nine years after 1998, to 2007.

\section{Datasets}

For comparison of numbers with earlier results, two datasets have been used recently (Bannister, 1997):

(1) animals seen in the 'WA sector', Cape Leeuwin-East of Israelite Bay, WA;

(2) animals seen in the 'WA-SA Sector', Cape Leeuwin, WA-Ceduna, SA.

For (1), the greatest number recorded on any flight in one year where two or more flights have been completed has been used in past comparisons. Allowance has been made for resights between legs on each flight. Data are categorised into three classes: (a) 'all' animals; (b) 'other' animals, i.e. those not accompanied by calves of the year; and (c) 'cow-calf pairs'. Counts have been made annually over the 22-year period 1976-97, but in the early years the coverage varied somewhat, either geographically or temporally; directly comparable data are available from 1983, apart from two years when bad weather prevented completion of the programme (Table 1: Area A). Dataset (2) allows comparison only from 1993 (Table 2). Because that survey regime was adopted to obviate the possible effect of between-year movement between the WA and SA sectors (Bannister, 1993), in due course the most valid comparison should involve that dataset.

For the 'WA sector', a geographically more extensive but temporally more restricted dataset can be used for year-to-year comparison, from 1986 but with no data for 1988-91 (Table 1: Area B). It includes a larger number of animals, particularly 'other' animals (non cow-calf pairs, (b)) now being found to the west of Twilight Cove, as well as those (often cow-calf pairs, (c)) congregating in the Cove itself.

The two 'short' flight datasets show a decrease in numbers in all classes for the WA sector in 1997 (Table 1: A, B). The same is true for the 'long' flight set for the WA-SA sector for cow-calf pairs (Table 2, c). Bad weather was encountered on much of the latter flight in 1997 (winds were greater than 30 knots on several occasions), and some undercounting may have resulted. The programme received a major setback with the sudden death in early 1996 of the pilot, John Bell, who
Table 1

Southern right whales, aerial survey, Western Australia: Numbers seen (Areas A, B : 'short' flights) 1983-97. a = all animals; $b=$ 'other' animals, i.e. those unaccompanied by calves; $c=$ cow-calf pairs.

\begin{tabular}{|c|c|c|c|c|c|c|}
\hline \multirow[b]{3}{*}{ Year } & \multicolumn{3}{|c|}{ Area A } & \multicolumn{3}{|c|}{ Area B } \\
\hline & \multicolumn{3}{|c|}{$\begin{array}{l}\text { C. Leeuwin - East of } \\
\text { Israelite Bay }\end{array}$} & \multicolumn{3}{|c|}{$\begin{array}{c}\text { C. Leeuwin - Twiligh } \\
\text { Cove }\end{array}$} \\
\hline & a & $b$ & $\mathrm{c}$ & $\mathrm{a}$ & $\mathrm{b}$ & c \\
\hline 1983 & 27 & 5 & 11 & & & \\
\hline 1984 & 54 & 26 & 14 & & & \\
\hline 1985 & 47 & 29 & 9 & & & \\
\hline 1986 & 50 & 12 & 19 & 63 & 24 & 24 \\
\hline 1987 & 63 & 37 & 13 & 71 & 46 & 13 \\
\hline 1988 & 75 & 39 & 18 & & & \\
\hline $1989^{1}$ & $\lceil 64$ & 22 & 211 & & & \\
\hline 1990 & 93 & 49 & 22 & & & \\
\hline $1991^{1}$ & {$[58$} & 32 & 131 & & & \\
\hline 1992 & 84 & 44 & 20 & 91 & 45 & 23 \\
\hline 1993 & 109 & 39 & 35 & 128 & 50 & 39 \\
\hline 1994 & 112 & 66 & 28 & 132 & 96 & 28 \\
\hline 1995 & 122 & 54 & 34 & 164 & 90 & 37 \\
\hline 1996 & 143 & 71 & 36 & 171 & 95 & 38 \\
\hline 1997 & 96 & 40 & 28 & 152 & 84 & 34 \\
\hline
\end{tabular}

Table 2

Southern right whales, aerial survey, Southern Australia, between C. Leeuwin, WA and Ceduna, SA: Numbers seen (Area C: 'long' 1lights) 1993-97. $a=$ all animals; $b=$ 'other' animals, i.e. those unaccompanied by calves; $\mathrm{c}=\mathrm{cow}$-call pairs.

\begin{tabular}{rrrr}
\hline Year & $\mathrm{a}$ & $\mathrm{b}$ & $\mathrm{c}$ \\
\hline 1993 & 182 & 56 & 63 \\
1994 & 199 & 101 & 49 \\
1995 & 255 & 125 & 65 \\
1996 & 233 & 123 & 55 \\
1997 & 254 & 148 & 53 \\
\hline
\end{tabular}

had been responsible for all flights since their beginning in 1976. Excellent replacements have been found but on the 'long' flight, particularly, there have been difficulties in selecting the necessary period of four consecutive 'good' weather days. There is also the disadvantage that in 1996 and 1997 the 'long' flight aircraft was based at Port Lincoln, SA, to the east of the survey area, and had to fly into the prevailing weather systems on its first leg, westwards.

\section{Trends}

Table 3 (the results of the best-fit straight line regressions to the natural logarithms of the data, plotted in Fig. 4) shows highly significant regressions for all WA sector datasets, i.e. Areas A and B, classes (a), (b) and (c). The point estimates (range 7.1-13.5) are somewhat high by comparison with those (of $\mathrm{ca} \mathrm{7 \%}$ ) from elsewhere, i.e. Argentina $(7.1 \%$, Payne et al., 1990) and South Africa $(7.2 \%$, Best et al., 2001). Nevertheless, the $95 \%$ confidence ranges for the WA sector all encompass, or are close to, the $7 \%$ value.

The increase rate for one of the three sets of WA-SA sector ('long' flight) results ('other animals', Table 3: Area $\mathrm{C}$, (b)) is significant at the $95 \%$ level but with a very wide confidence interval, and for another set ('all animals', (a)) is approaching it, as expected from the power analysis. The rate for cow-calf pairs (c) does not yet show a positive increase. 

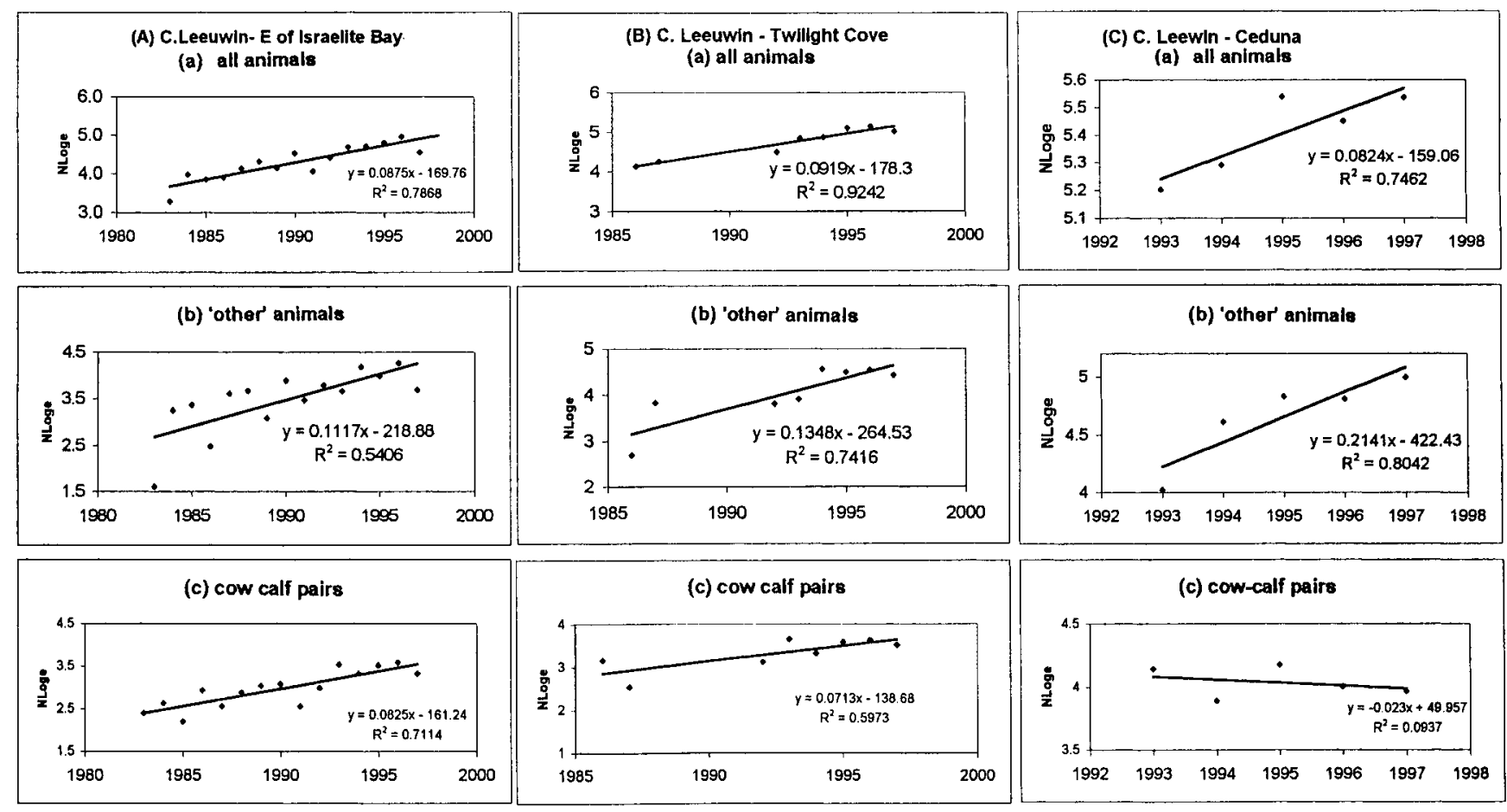

Fig. 4. Regressions for data of Tables 1-3.

Table 3

Best fit regressions to data $(\log e$ ) of Tables 1 (Areas A, B) and 2 (Area C). $a=$ all animals; $b=$ 'other' animals, i.e. those unaccompanied by calves; $\mathrm{c}=$ cow-calf pairs.

\begin{tabular}{|c|c|c|c|c|c|c|c|c|c|}
\hline & \multicolumn{3}{|c|}{ Area A } & \multicolumn{3}{|c|}{ Area B } & \multicolumn{3}{|c|}{ Area C } \\
\hline & a & $\mathrm{b}$ & $\mathrm{c}$ & $\mathrm{a}$ & $\mathrm{b}$ & $\mathrm{c}$ & $\mathrm{a}$ & $\mathrm{b}$ & $\mathrm{c}$ \\
\hline$\%$ rate of increase & 8.7 & 11.2 & 8.3 & 9.2 & 13.5 & 7.1 & 8.2 & 21.4 & -2.3 \\
\hline P-value & 0.0000 & 0.0018 & 0.0001 & 0.0001 & 0.0060 & 0.0245 & 0.0591 & 0.0392 & 0.6164 \\
\hline $95 \%$ range of increase & $6.0-11.5$ & $5.0-17.3$ & $5.1-11.4$ & $6.6-11.8$ & $5.5-21.5$ & $1.3-12.9$ & $-0.0-7.1$ & $1.9-40.8$ & \\
\hline
\end{tabular}

The latter is to be expected given possible differences in cohort strength (see below) and the need, as demonstrated in the 1997 power analysis, for the surveys to cover five calving cycles.

The observed three-year calving cycle (as described for example in Bannister, 1990) could be expected to lead to differences in cohort strength. That is now becoming more readily apparent in the longer data series for the WA sector (Table 4, Areas A and B). The slopes of two regressions (Table 5, plotted in Fig. 5) are significant at the 95\% level, and their increase rates (point estimates 7.7, 9.6\%) are similar to those obtained for the cow-calf data as a whole in that sector (Table 3, A and B, (c)) but with much wider confidence intervals.

\section{POPULATION SIZE}

The survey methodology, originally adopted in 1976, has been deliberately continued over the years with as little change as possible to provide a comparable annual index of abundance; it was not developed at the outset to provide an absolute value. With only a very small number of additional animals recorded on survey 'return' legs, however, the counts obtained on the outward legs can be adjusted to represent a reasonably accurate estimate of the actual numbers close to the coast at that time, particularly the relatively sedentary and easily visible cow-calf pairs. On that basis it is appropriate to base an estimate of current population size on those figures, representing the maximum number of cow-calf pairs present at the peak of the season.

A naive model assumes that: (1) each female is recorded on the coast only once in three years; (2) there is no difference in the size of the adult female cohort each year; (3) the sex ratio is unity; (4) there are probably some unreproductive adult females present; and (5) in an expanding population there are at least as many immature animals as adults. Some of those assumptions are not likely to be met over a long period: calving female cohort size, for example, has varied over the five years 1993-97 from 49-65 (Table 2). That immature animals are likely to number at least as many as adults is conservative. Rice and Wolman (1971) for example, calculated that $61 \%$ of the eastern North Pacific gray whale population would have been immature at that time, when the population increase rate was averaging some 3\% (Anon., 1993). Zeh et al. (1993) strongly suggested that in the slowly increasing Bering-Chukchi-Beaufort Seas bowhead population half or fewer than half of the animals were mature, although some of that might have been due to late sexual maturity ${ }^{2}$. Taking such considerations into account, the assumptions are appropriate for estimating at least a minimum current population size.

\footnotetext{
2 The Cape Town Assessment Meeting (item 10.3.2) recorded the ratio of juveniles and calves to adults in southern right whale populations as $1.4: 1$ as a consequence of the relatively high population growth rate.
} 
Cohort 1
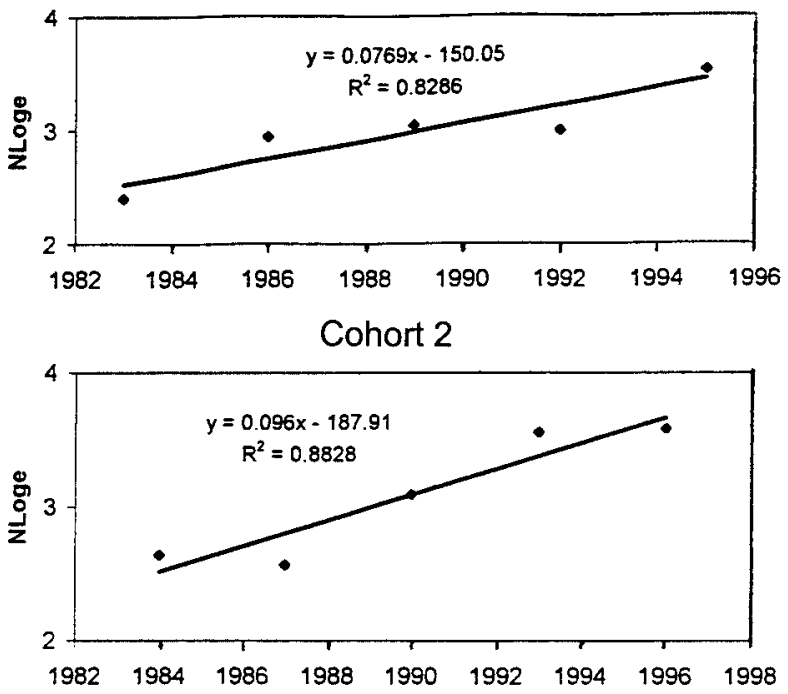

Cohort 3

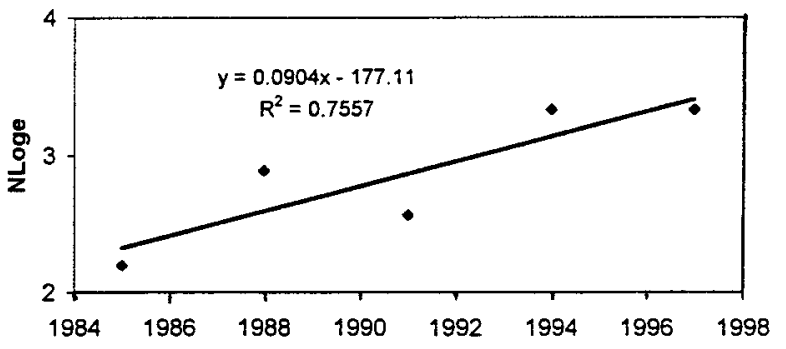

Fig. 5. Regressions for data of Table 4.

Table 4

Western Australia south coast, 1983-97.

Numbers of cow-calf pairs recorded at three year intervals. Data from Table 1. 1, 2,3= cohorts.

\begin{tabular}{|c|c|c|c|c|c|c|}
\hline & \multicolumn{3}{|c|}{ Area A } & \multicolumn{3}{|c|}{ Area B } \\
\hline & 1 & 2 & 3 & 1 & 2 & 3 \\
\hline 1983 & 11 & & & & & \\
\hline 1984 & & 14 & & & & \\
\hline 1985 & & & 9 & & & \\
\hline 1986 & 19 & & & 24 & & \\
\hline 1987 & & 13 & & & 13 & \\
\hline 1988 & & & 18 & & & \\
\hline 1989 & [21] & & & - & & \\
\hline 1990 & & 22 & & & - & \\
\hline 1991 & & & [13] & & & - \\
\hline 1992 & 20 & & & 23 & & \\
\hline 1993 & & 35 & & & 39 & \\
\hline 1994 & & & 28 & & & 28 \\
\hline 1995 & 34 & & & 37 & & \\
\hline 1996 & & 36 & & & 38 & \\
\hline 1997 & & & 28 & & & 34 \\
\hline
\end{tabular}

Table 5

Best lit regressions to data from Table 4 (Area A only). $1,2,3=$ cohorts.

\begin{tabular}{lccc}
\hline & $1: 1983+$ & $2: 1984+$ & $3: 1985+$ \\
\hline Increase $(\%)$ & 7.7 & 9.6 & 9.0 \\
p-value & 0.0318 & 0.0177 & 0.0556 \\
$95 \%$ range of increase & $1.3-14.1$ & $3.2-16.0$ & $-0.0-18.5$ \\
\hline
\end{tabular}

From the 'long flight' counts in 1995-97, the average number of reproductive females visiting the coast each year is 57. The minimum number of adult females in the population would then be 171 , with a total adult population of more than 342. Allowing for immature animals, the size of the population visiting Australia's southern coast, i.e. between Cape Leeuwin, WA and Ceduna, SA over that period, 1995-97, would then be at least $684^{3}$.

\section{ACKNOWLEDGEMENTS}

This paper is dedicated to the memory of John Bell, 1933-96, who up to 1995 piloted every flight from the beginning of the surveys in 1976, and without whose skills the data used here would not have been available. Over the years he was assisted first by Ray Smith and then by Alan Murdoch as observer/photographer. In 1996 and 1997, 'short' flights were piloted by Jenny Schmidt, with observer/photographer Andrew Halsall, and 'long' flights by John Rogers, accompanied by Ian Westhorpe. Many others have assisted over the years, including Gordon Anderson, Stuart Anstee, Scott Baker, John Bannister Jr., Paddy Berry, Peter Best, Lynne Broomhall, Stephen Burnell, Chris Burton, Nick Caputi, Graham Chittleborough, Peter Collins, Peter Corkeron, Doug Coughran, the late Bill Dawbin, Greg Donovan, Douglas Elford, Richard Holst, Hidehiro Kato, Cath Kemper, Geoff Kirkwood, Peter Lambert, John Ling, Astrida Mednis, Dave Mell, Pin Needham, Anne Nevin, Val Milne, Luis Pastene, Roger Payne, Deborah Thiele, Bob Warneke and the Trustees and staff of the Western Australian Museum. Dr Catherine Kemper (South Australian Museum, North Terrace, Adelaide, South Australia 5000, Australia) and Stephen Burnell (Department of Veterinary Anatomy and Pathology, University of Sydney, New South Wales 2600, Australia) commented on a draft typescript.

Surveys have been undertaken under permit from the relevant Western Australian and South Australian state authorities. Since 1978 they have been funded by Environment Australia, Biodiversity Group, and its predecessors.

\section{REFERENCES}

Aitken, P.F. 1981. Whales from the coast of South Australia. Trans. R. Soc. S. Aust. 95(2):95-103.

Anonymous. 1993. Report of the special meeting of the Scientific Committee on the assessment of gray whales. Rep. int. Whal. Commn 43:241-59.

Bannister, J.L. 1986. Notes on nineteenth century catches of southern right whales (Eubalaena australis) off the southern coasts of Western Australia. Rep. int. Whal. Commn (special issue) 10:255-9.

Bannister, J.L. 1990. Southern right whales off western Australia. Rep. int. Whal. Commn (special issue) 12:279-88.

Bannister, J.L. 1993. Report on aerial survey for right whales off southern Western Australia, 1992. Unpublished report to the Australian Nature Conservation Agency. 19pp. [Available from: Environment Australia, Marine Species Section, GPO Box 787, Canberra, ACT, Australia].

Bannister, J.L. 1994. Report on aerial survey for southern right whales off southern Australia, 1994. Unpublished report to the Australian Nature Conservancy Agency. 16pp. [Available from: Environment Australia, Canberra].

Bannister, J.L. 1997. Aerial survey of southern right whales off Western and South Australia, 1995 and 1996 calving seasons: report on work undertaken to 1 March 1997. Unpublished report to the Australian Nature Conservation Agency. 27pp. [Available from: Environment Australia, Canberra].

Bannister, J., Burnell, S., Burton, C. and Kato, H. 1997. Right whales off southern Australia: direct evidence for a link between onshore

${ }^{3}$ The Cape Town Assessment Meeting (Table 4), based on the 1995 reproductive female figure of 65 for the area Cape Leeuwin-Ceduna, allowing for additional animals off the remainder of the Australian coast, and using a more sophisticated analysis, estimated current (1997) population size for the 'Australian' population as 1,197; the pro rata figure for that part of the population visiting the area Cape Leeuwin-Ceduna is 848 . 
breeding grounds and offshore probable feeding grounds. Rep. int. Whal. Commn 47:441-4.

Bannister, J.L., Pastene, L.A. and Burnell, S.R. 1999. First record of movement of a southern right whale (Eubalaena australis) between warm water breeding grounds and the Antarctic Ocean, South of 60ํ․ Mar. Mammal Sci. 15(4):1337-42.

Best, P.B. 1970. Exploitation and recovery of right whales Eubalaena australis off the Cape Province. Investl Rep. Div. Sea Fish. S. Afr. 80:1-20.

Best, P.B. and Schell, D.M. 1996. Stable isotopes in southern right whale (Eubalaena australis) baleen as indicators of seasonal movements, feeding and growth. Mar. Biol. 124(4):483-94.

Best, P.B., Brandão, A. and Butterworth, D. 2001. Demographic parameters of southern right whales off South Africa. J. Cetacean Res. Manage. (special issue) 2:161-169.

Burnell, S.R. 1997. An incidental flight network for the photo-identification of southern right whales off southeastern Australia. A summary of research activities undertaken in the 1995 and 1996 seasons. Report by Eubalaena Pty. Ltd to BHP Petroleum Pty. Ltd. and Esso Australia Ltd. 30pp.

Burnell, S.R. 2001. Aspects of the reproductive biology, movements and site fidelity of right whales off Australia. J. Cetacean Res. Manage. (special issue) 2: 89-102.

Burnell, S.R. and Bryden, M.M. 1997. Coastal residence periods and reproduction timing in southern right whales (Eubalaena australis). J. Zool., Lond. 241:613-21.

Chittleborough, R.G. 1956. Southern right whale in Australian waters. J. Mammal. 37(3):456-7.

Dakin, W.J. (ed.). 1934. Whalemen Adventurers. Angus and Robertson Limited, Sydney. 263pp.

Dawbin, W.H. 1986. Right whales caught in waters around south eastern Australia and New Zealand during the nineteenth and early twentieth centuries. Rep. int. Whal. Commn (special issue) 10:261-7.

Haley, N.C. 1950. Whale Hunt, the Narrative of a Voyage. Robert Hale, London. 319pp.

Kemper, C.M., Mole, J., Warneke, R.M., Ling, J.K., Needham, D.J. and Wapstra, J.D. 1997. Southern right whales in south eastern Australia - aerial surveys during 1991-93 and incidental information from 1904. pp. 40-5. In: M. Hindell and C. Kemper (eds.) Status, Ecology and Medicine. Vol. 1. Marine Mammal Research in the Southern Hemisphere. Surrey Beatty and Sons Pty Ltd, Chipping Norton, New South Wales.

Ling, J.K. and Aitken, P.F. 1981. Marine mammals in South Australia. In: S.A. Year Book 1981. Australian Bureau of Statistics, Adelaide.

Ling, J.K. and Needham, D.J. 1991. Southern right whales survey: South Australian calving season. Final Report to the ANCA (ANPWS) (unpublished). 17pp.

Ohsumi, S. and Kasamatsu, F. 1986. Recent off-shore distribution of the southern right whale in summer. Rep. int. Whal. Commn (special issue) $10: 177-85$.

Patenaude, N.J. and Baker, C.S. 2001. Population status and habitat use of southern right whales in the sub-Antarctic Auckland Islands of New Zealand. J. Cetacean Res. Manage. (special issue) 2:111-116.

Payne, R., Rowntree, V., Perkins, J.S., Cooke, J.G. and Lankester, K. 1990. Population size, trends and reproductive parameters of right whales (Eubalaena australis) off Peninsula Valdes, Argentina. Rep. int. Whal. Commn (special issue) 12:271-8.

Rice, D.W. and Wolman, A.A. 1971. The Life History and Ecology of the Gray Whale (Eschrichtius robustus). American Society of Mammalogists, Special Publication No. 3, Stillwater, Oklahoma. viii+142pp.

Tormosov, D.D., Mikhalev, Y.A., Best, P.B., Zemsky, V.A., Sekiguchi, K. and Brownell Jr, R.L. 1998. Soviet catches of southern right whales, Eubalaena australis, 1951-1971; biological data and conservation implications. Biol. Conserv. 86(2):185-97.

Townsend, C.H. 1935. The distribution of certain whales as shown by logbook records of American whaleships. Zoologica (NY) 19(1-2):1-50+6 maps.

Whitecar, W.B. 1860. Four Years Aboard the Whaleship. Embracing Cruises in the Pacific, Atlantic, Indian and Antarctic Oceans in the Years 1855, '6, '7, '8, '9. J.B. Lippincott \& Co, Philadelphia; Trubner \& Co., London. 413pp.

Zeh, J.E., Clark, C.W., George, J.C., Withrow, D., Carroll, G.M. and Koski, W.R. 1993. Current population size and dynamics. pp. 409-89. In: J.J. Burns, J.J. Montague and C.J. Cowles (eds.) Special Publication. No. 2. The Bowhead Whale. The Society for Marine Mammalogy, Lawrence, Kansas. 787pp. 